\title{
Os Contratos de Receita e a licitação na Modalidade de Preqũo
}

\section{Reginaldo Arnold}

\section{INTRODUÇÃo}

O presente trabalho tem por objetivo avaliar a possibilidade, ou não, de a Administração Pública valer-se da modalidade licitatória do pregão para celebrar contratos de receita.

Para tanto, iniciar-se-á o estudo relembrando os tipos de contratos públicos segundo o direcionamento dos seus recursos financeiros, passando-se imediatamente a verificar se a concessão administrativa de uso é sinônima de locação e se podem ser eles considerados como serviços comuns para fins de aplicação da Lei no 10.520/02.

Superada essa etapa, verificar-se-ão os principais óbices ao uso da modalidade licitatórta do pregão nas situações sob estudo, buscando-se precedentes mais próximos possíveis já julgados pelo Tribunal de Contas da União e apresentando ao leitor as conclusões extraídas da pesquisa doutrinária e jurisprudencial.

\section{OS CONTRATOS DA ADMINISTRAÇÃO PÚBLICA}

A Administração Pública, para suprir suas próprias necessidades internas (exemplos: material de consumo, serviços de limpeza), bem como para desempenhar sua função junto aos administrados necessita celebrar contratos com terceiros. Esses contratos, de acordo com o ingresso ou desembolso de recursos públicos são classificados, respectivamente, como sendo de receita (exemplo: cessão de uso onerosa) ou de despesa (exemplo: aquisição de material de consumo). 
Há, ainda, os contratos em Que não há desembolso nem ingresso de recursos públicos, casos em Que são denominados de contratos (se os interesses são diversos e opostos) ou convênios (se os interesses forem idênticos, comuns) sem ônus (exemplo: contrato de cessão de uso gratuito de imóvel da União a Estados ou Municípios').

A legislação é pródiga em regular os contratos de despesa, como são exemplos a Lei $\Pi^{\circ} 8.666 / 93$ e a Lei $n^{\circ} 10.520 / 02$. Con relação aos contratos de receita, todavia, pouca regulamentação há. Quando muito, há uma breve remissão aos "procedimentos licitatórios previstos em lei." ${ }^{2}$

A Lei no $8.666 / 93$, por sua vez, única existente nessa época, destina-se a estabelecer "normas gerais sobre licitações e contratos administrativos pertinentes a obras, serviços, inclusive de publicidade, compras, alienações e locações no âmbito dos Poderes da União, dos Estados, do Distrito Federal e dos Municípios"3. Excetuando a palavra "alienações", Que é contrato de receita e se destina à perda da propriedade ${ }^{4}$, as demais se referem aos contratos de despesa ${ }^{5}$.

Daí porQue, na ausência de normas específicas para os contratos de receita passouse a utillizar, por analogia, das previsões para a celebração dos contratos de despesa, adequandoos àQueles casos. Exemplos: escolha da modalidade licitatória (convite, tomada de preços ou concorrência) do contrato de receita de acordo com o valor de avaliação pela administração (pesquisa do valor de mercado) para fins de cessão de uso oneroso do bem público multiplicado pelo número de meses de vigência (incluídos os meses de eventuais prorrogações) do contrato a ser celebrado; limite contratual do contrato de receita em sessenta meses ${ }^{6}$.

Depois, ao Que consta, inexiste em doutrina e jurisprudência oposição ao uso dessas tradicionais modalidades licitatórias para os contratos de receita. Cumpre agora indagar da possibilidade, ou não, do uso da novel modalidade licitatória denominada pregão, o Qual pode ser presencial ou eletrônico.

1 Artigo 18, caput e 1, ambos da Leî no 9.636/98: "A critério do Poder Executivo poderão ser cedidos, gratuitamente ou em condiçöes especiais, sob Qualquer dos regimes previstos no Decreto-Lei $n^{\circ} 9.760$, de 1946, imóveis da Uniấo a: I - Estados, Municípios (...)".

2 Artigo $18, \S 5^{\circ}$, da Leł n $n^{\circ} 9.636 / 98$ : "A cessão, Quando destinada à execuçăo de empreendimento de fim lucrativo, será onerosa e, sempre Que houver condições de competitividade, deverão ser observados os procedimentos licitatórios previstos em lei.".

3 Artigo $1^{\circ}$ da Lei $n^{\circ} 8.666 / 93$.

4 Artigo $22, \S 5^{\circ}$, da Lei $n^{\circ} 8.666 / 93$.

5 Nesse sentido, o artigo $40, X$, da Lei $n^{\circ} 8.666 / 93$, pois obriga a existência, no edilal, de cláusula com critério de aceitabilidade dos preços, permitindo a fixaçăo de preço máximo e vedando a de preço míntmo. Quando, no contrato de teceita, deve-se proceder de modo inverso.

6 Artigo 57, Il, da Lei $n^{\circ} 8.666 / 93$. 


\section{A MODALIDADE LICITATÓRIA DO PRECÃo}

O pregão, presencial ou eletrônico, encontra-se atualmente regulado pela Lei n ${ }^{\circ}$ 10.520/02 e pelo Decreto ${ }^{0}$ 3.555/00. Dispõem, respectivamente, esses atos: "Art. $\left.\right|^{\circ}$. Para aQuisição de bens e serviços comuns, poderá ser adotada a licitação na modalidade de pregão, Que será regida por esta Lei." e "Art. $1^{\circ}$. Este regulamento estabelece normas e proce dimentos relativos à licitação na modalidade de pregão, destinada à aQuisição de bens e serviços comuns, no âmbito da Uniāo, QualQuer Que seja o valor."

\subsection{O Prequão e Rol de Bens e Serviços Comuns do Decreto 3.555/00}

Ao dispor acerca da "aQuisição de bens e serviços comuns", o artigo $1^{\circ}$ da Lei $n^{\circ}$ 10.520/02, em seu parágrafo único, estabelece que se consideram como tais "aqueles cujos padróes de desempenho e Qualidade possam ser objetivamente definidos pelo edital, por meio de especificações usuais no mercado." O parágrafo $2^{\circ}$ do artigo $3^{\circ}$ do Decreto $n^{\circ}$ 3.555/00 acrescenta, ainda, a expressão "de acordo com o disposto no Anexo ll."

Assim, efetuando-se uma interpretação literal e estrita do disposto nesse decreto, chegar-se-ia à conclusão de Que o rol dos bens e serviços comuns do Anexo Il seria exaustivo, não se admitindo, portanto, o uso do pregão para outras hipóteses Que não as ali expressamente previstas.

Essa não é, contudo, a methor interpretação do dispositivo do Decreto, pois: a um, o Decreto não pode restringir a Lei, na medida em que esta possui hierarquia superior àQuele; a dois, o Decreto é anterior à Lei; a três, considerando-se isoladamente o Decreto (ou seja, sem levar em linha de conta o disposto no ato normativo do Legislativo), há outros métodos de interpretação mais ricos do Que o da literalidade ; a quatro, na colidência de disposições entre o Decreto e a Legislação deve prevalecer esta em detrimento daquele, o Qual será considerado ilegal; e, a cinco, no que tange ainda ao Decreto, o que se poderia fazer é uma interpretação "conforme a lei" (à semelhança da interpretação conforme a Constituiç̧ão), para dizer que a lista do anexo é meramente exemplificativa, pois o princípio da interpretação conforme é procedimento não de mera hermenêutica, mas, sim, de controle propriamente dito ${ }^{8}$.

7 Nesse sentido: "(...) acredito que o intérprete não deve restringir a interpretação da lei à sua literalidade, mas deve buscar tarnbém, sobretudo, a sua linalidade. O interesse público deve nortear a interpretação, considerando-se que a finalidade da lei sempre é o atendimento ao interesse público." em PELEGRIN!, Márcia. Pregão - O conceito de "bens e serviços comuns". BLC - Boletim de licitaçöes e Contratos, SP, jun. 2003, p. 402.

8 BRASIL. Supremo Tribunal Federal. Representação de Inconstitucionalidade no 1417/DF, Plenário. Relator: Ministro Moreira Alves, Brasilia, DF, sessão de 09 de dezembro de 1987, D) de 15 de abril de 1988, p. 8397. 
MARÇAL JUSTEN FILHO ${ }^{9}$ e CARLOS PINTO COELHO MOTTA ${ }^{10}$, bem COmo o Tribunal de Contas da Uniāo" ", corroboram o entendimento de que o rol de bens e serviços comuns do anexo II é meramente exemplificativo. Aquele doutrinador, inclusive, entende Que não basta estar o bem ou serviço elencado no rol do anexo ll do Decreto $\pi^{\circ} 3.555 / 00$, devendo ele ser considerado comum na situação específica ${ }^{12}$.

O Tribunal de Contas da União, por sua vez, tem admitido o uso do pregão inclusive em casos de conflito aparente de normas do próprio decreto. Dada a importância do acórdão nessa matéria, transcreve-se, a seguir, os seus principais trechos:

"7.5. Temos, então, numa mesma norma jurídica, o Dec. $n^{0} 3.555 / 00$, dois dispositivos conflitantes, o Anexo I, art. 5०, Que impede o uso do pregão para aquisição de obras e serviços de engenharia, e o Anexo ll, Que autoriza serem licitados na modalidade pregão os serviços de manutenção de bens móveis e imóveis. Ensina a boa técnica de interpretação Que, em normas de mesmo valor hierárquico, o específico deve prevalecer sobre o geral. ConseQüentemente, a proibição contida no art. $5^{\circ}$ sucumbe diante da clara manifestação do Anexo Il. Isto é, os serviços de manutenção de bens móveis e imóveis, mesmo sendo serviços de engenharia, podem ser licitados na modalidade pregão." ${ }^{3}$

E, na fundamentação, assim constou:

"No mérito, considerando que restou demonstrado nos autos a inexistência de óbice legal para Que os serviços pretendidos pela ECT sejam licitados na modalidade pregão, por se tratar de fornecimento de mão-de-obra especializada para a prestação de serviços de manutenção de bens móveis, penso Que não deve prosperar a pretensão do Conselho Regional de Engenharia, Areuitetura e Agronomia do Distrito Federal." ${ }^{4}$

9 IUSTEN FILHO, Marçal. Pregão: (comentários à legislação do pregão comum e eletrónico). SP: Dialética, 2004, p. 33.

to MOTTA, Carlos Pinto Coelho. Pregão: teoria e prática: nova e antiga idéia em licitação pública. SP: NDJ, 2001, p.32.

$"$ BRASIL. Tribunal de Contas da União. Acórdão no 615/2003 em Represcntação no 001.148/2003-9, da Primeira Câmara. Entidade: Conselho da Justiça Federal. Relator: Ministro Humberto Guimarães Souto, Brasília, DF, sessão de 01 de abril de 2003, DOU de 09 de abrił de 2003 c BRASIL. Tribunal de Contas da União. Acórdão no 313/2004 em Representação no 012.678/2002-5, do Plenário. Entidade: Caixa Econômica Federal - CAIXA. Relator: Ministro Benjamin Zymler, Brasília, DF, sessão de 24 de março de 2004, DOU de 07 de abril de 2004.

12 IUSTEN FilHo, Marçal. Pregão: (comentários à legislação do pregão comum e eletrônico). SP: Dialética, 2004, p. 33.

13 BRASIL: Tribunal de Contas da Uniäo. Decisão no 674/02 em Representação no TC-015:199/01-3, do Plcnário. Relator: Ministro Iam Saraiva, Brasilia, DF, DOU de 08 de julho de 2002.

${ }^{14}$ BRASIL. Tribunal de Contas da União. Decisão n 674/02 em Representaçăo n ${ }^{\circ}$ TC-015.199/01-3, do Plenário: Relator: Ministro Iram Saraiva, Brasília, DF, DOU de 08 de jutho de 2002. 
A conclusão, portanto, é que o rol de bens e serviços comuns do anexo ll do Decreto $\mathrm{n}^{\circ} 3.555 / 00$ é meramente exemplificativo e Que se faz possível o uso do pregão para situações Que, em tese, o próprio decreto teria inicialmente vedado.

Daí porque a doutrina de MÁRCIA PELEGRINI ${ }^{15}$ e de SIDNEY BITTENCOURT ${ }^{16}$ term reconhecido que a terminologia "bens e serviços comuns" são conceitos indeterminados.

\subsection{Aouisição de Bens e Serviços Comuns a as Licitações}

O pregão, segundo o conceito legal ${ }^{17}$, destina-se à aquisiçâo de bens e serviços comuns. CARLOS PINTO COELHO MOTTA, ao efetuar distinção entre aQuisição e serviços, resta por afirmar que "em outras palavras, cabe a clássica distinção doutrinária entre compra e serviço - a primeira, obrigação de dar; e o segundo, obrigação de fazer."

Embora se entenda o sentido dessa comparação, poder-se-ia chegar à concíusão, pelo texto legal, de Que é possível "adeuirir" "serviços comuns", o que geraria um problema de classificação da obrigação, na medida em Que ela seria, ao mesmo tempo, de dar e de fazer.

Há casos práticos, como o da aquisição de persianas com instalação, por exemplo, em Que o administrador possui dificuldade em classificar o edital como sendo de compra ou de serviço. Recomenda-se, nesses casos, Que a classificação seja realizada pela atividade preponderante, ou seja, no exemplo citado, seria realizada uma compra, e não um serviço, na medida em que a instalação ("fornecimento") seria mera decorrência da ąuisição.

Superada essa Questấo, de classificação dentre as hipóteses legais, cumpre examinar se o pregão constituir-se-ia em uma nova modalidade licitatória, para além daquelas já previstas na Lei 8.666/93. MARÇAL JUSTEN FILHO, ao abordar essa Questão, assim se manifesta:

"O pregão se constitui em outra modalidade licitatória, além daeuelas previstas na Lei no $8.666 . " 19$

"Configurar o pregão como uma modalidade licitatória significa adotar um novo procedimento (...) para seleção da proposta mais vantajosa, com observância do princípio da isonomia." 20

is PELEGRINI, Márcia. Pregão - O conceito de "bens e serviços comuns". BLC - Boletín de Licitações e Contratos, SP, jun. 2003, p. 399.

is BITTENCOURT, Sidney. Bens e serviços comuns a serem adquiridos ou contratados por meio de pregão. DCAP - Direito Administrativo, Contabilidade e Administração Pública, SP, nov. 2002, p. 22.

${ }^{17}$ Artigo $1^{\circ}$ da Lei ${ }^{\circ} 10.520 / 02$. Ver, também, o artigo $1^{\circ}$ do Decreto $n^{\circ} 3.555 / 00$.

18 MOTTA, Carlos Pinto Coelho. Pregão: teoria e prática: nova e antiga idéia em licitaçăo pública. SP: NDI, 2001, p. 20.

19 JUSTEN FILHO, Marçal. Pregão: (comentários à legislação do pregão comum e eletrônico). SP: Dialética, 2004, p. 17.

20 JUSTEN FILHO, Marçal. Pregão: (comentários à legislaçăo do pregão comum e eletrônico). SP: Dialética, 2004, p. 18. 
"O que diferencia uma modalidade de outra é a estruturação procedimental, a forma de elaboração de propostas e o universo de possíveis participantes. "21

Nesse mesmo sentido é o posicionamento de IESSÉ TORRES PEREIRA JÚNIOR ${ }^{22} \mathrm{~A}$ resposta é, portanto, a de Que, atualmente, há seis modalidades diversas de licitação, Que se distinguem de acordo com o valor (convite, tomada de preços e concorrência) ou a sua finalidade (concurso, leilão e pregão).

Depois, se a expressão "aquisição" (comprar) do conceito legal ${ }^{23}$ referir-se apenas aos bens, seria possível à administração "alienar" (vender) seus serviços ${ }^{24}$ comuns, como o fazia através das outras modalidades licitatórias ${ }^{25}$ ? Entendo Que sim, pois o fornecimento ${ }^{26}$ depende, apenas, do pólo em Que, na situação concreta, a Administração se encontra.

\subsection{Locação, Arrendamento e Cessão de Uso}

$\mathrm{O}$ artigo 20 da Lei no $9.636 / 98$ estabelece a possibilidade de "cessão de uso a terceiros, a título gratuito ou oneroso, de áreas para exercício de atividade de apoio, definidas em regulamento, necessárias ao desempenho da atividade do órgão a Que o imóvel fó entregue." $E$, em se tratando de execução de empreendimento de fim lucrativo, a cessão será onerosa $\mathrm{e}$, havendo competitividade, precedida de licitação. ${ }^{27}$

$\mathrm{O}$ artigo 12 do Decreto $\mathrm{n}^{\circ} 3.725 / 01$, por sua vez, ao regulamentar a lei antes mencionada, estabeleceu, como atividades de apoio, as seguintes: I - posto bancário; II posto dos correios e telégrafos; 111 - restaurante e lanchonete; $\mathrm{V}$ - central de atendimento a saúde; $V$-creche e VI - outras atividades similares necessárias.

Assim, em se tratando de atividade de apoio, o instituto jurídico que tem sido utilizado é o da cessão de uso, por força do disposto no artigo 20 da Lei no 9.636/98, o qual possui a seguinte redação:

"Art. 20. Não será considerada utilização em fim diferente do previsto no termo de entrega, a Que se refere o $\$ 2^{\circ}$ do art. 79 do Decreto-Lei $\pi^{\circ} 9.760$, de 1946, a cessão de uso a terceiros, a título gratuito ou oneroso, de áreas para exercício de atividade de apoio, definidas em regulamento, necessárias ao desempenho da atividade do órgão a Que o imóvel foi entregue."

${ }^{21}$ JUSTEN FILHO, Marçal. Pregão: (comentários à legislação do pregão comum e eletrônico). SP: Dialética, 2004, p. 18.

22 PEREIRA JúNIOR, Jessé Torres. Pregâo, a sexta modalidade de licitaçăo. DCAP - Difeito Administrativo, Contabilidade e Administração Pública, SP, jun. 2000, p. 7.

${ }^{23}$ Artigo $1^{\circ}$ da Lei $n^{\circ} 10.520 / 02$.

${ }^{24}$ Artigo $6^{\circ}$, II, da Lei $n^{\circ} 8.666 / 93$.

${ }^{25}$ Artigo $1^{\circ}$ da Lei $n^{\circ} 8.666 / 93$.

${ }^{26}$ Artigo $2^{\circ}$ do anexo 1 do Decreto $\pi^{\circ} 3.555 / 00$.

${ }^{27}$ Artigo $18, \S 5^{\circ}$, da let $n^{\circ} 9.636 / 98$. 
Fora dessas hipóteses, utiliza-se a cessão de uso sob o regime de arrendamento ${ }^{28}$. e não o da locação ${ }^{29}$, embora os atos normativos utilizem, indiscriminadamente ${ }^{30}$, esses termos como sinônimos.

HELY LOPES MEIRELLES ${ }^{3}$, ao abordar o tema da utilização dos bens públicos, explica:

Erroneamente, as Administraçōes têm feito concessōes remuneradas de uso de seus bens sob a imprópria denominação de locação, pretendendo submetêlas ao Código Civil ou às leis do inquilinato e até mesmo à lei de locações para fins comerciais, o que é inadmissivel tratando-se de uso especial de bem público. Também não se deve confundir a concessão gratuita de uso com o comodato, pois são institutos diferentes e sujeitos a normas diversas. A locação e o comodato são contratos de Direito Privado, impróprios e inadequados para a atribuição de uso especial de bem público a particular; em seu lugar deve ser sempre adotada a concessão de uso, remunerada ou gratuita, conforme o caso.

Há Que se considerar, ainda, a existência, ao lado das concessões de uso, do instituto da locação administrativa ${ }^{32}$, o Qual não se confunde com o da locação de direito privado ${ }^{33}$.

Veja-se que, curiosamente, 0 artigo $1^{\circ}$ da Lei $n^{\circ} 8.666 / 93$ refere-se aos serviços e às locaçóes (e este é, nos termos do próprio conceito lega ${ }^{34}$, um serviço), mas nada mencionou a respeito das concessões de uso. No entanto, logo no artigo seguinte, esse instituto jurídico restou pela lei abarcada, Quando, na verdade (segundo o princípio da legalidade estrita), não poderia (já Que houve omissão no primeiro artigo da lei sob comento). Vê-se, portanto. Que a interpretação literal não é o melhor método de hermenêutica, até porque a concessão administrativa de uso situa-se em uma zona gris, onde há um contrato de serviço (pela definição legal) que recai na tolerância, remunerada ou não, do uso de um bem público.

A Segunda Câmara do Tribunal de Contas da União, ao proferir a Decisão no 207/ $1995^{35}$, assim se pronunciou sobre o tema:

${ }^{28}$ Ver artigos 21 e 40 da Lei no 9.636/98 e artigos 64, 86 e 95 do Decreto-Lei no 9.760/46.

29 Ressalva-se, contudo, a cxistência da locação administrativa, em que a Administraçäo Pública ligura cono locadora, conforme dispõe o artigo 86 e seguintes do Decreto-Lei n $\pi^{\circ} .760 / 46$.

${ }^{30}$ Ver artigos 21 c 40 da Lei no 9.636/98; artigos 64, 86 e 95 do Decreto-Lei $n^{\circ} 9.760 / 46$ e artigo 17 , I, "f", da Lei $n^{\circ} 8.666 / 93$.

${ }^{31}$ MEIRELLES, Hely Lopes. Direito Administrativo Brasileiro. SP: Malheiros, 2002, p. 496-497.

32 Ver artigo 86 a 91 do Decreto-Lei $n^{\circ} 9.760 / 46$.

33 Artigo 87 do Decreto-Lei $n^{\circ}$ 9.760/46.

${ }^{3}$ Artigo 60, 11 , da Lei $n^{\circ} 8.666 / 93$.

35 BRASIL. Tribunal de Contas da União. Decisão n० 207/95 em Processo no TC-275.320/92-8, da Segunda Câmara. Relator: Ministro Adhemar Paladini Ghisi, Brasília, DF, sessăo de 17 de agosto de 1995 , DOU de 30 de agosto de 1995, p. 13360. 


\section{"(...)}

2. A concessão de uso, "lato sensu", engloba duas modalidades: a concessão administrativa de uso e a concessão de direito real de uso. Por se tratarem de institutos distintos, regem-se por normas próprias. Considerando Que a concessão de direito real de uso atribui o uso do bem público com um direito real, transferível a terceiros, requerendo, por isso, especial processo seletivo, mereceu destaque no Estatuto das Licitações. (...) 3. A concessão administrativa de uso, também denominada concessão comum de uso, apenas confere ao concessionário um direito pessoal, intransferivel a terceiros. Daí a menor rigidez em sua contratação. A maior flexibilidade conferida ao Administrador não se confunde, contudo, com desnecessidade de realização do procedimento licitatório, uma vez que caracterizada a predominância do interesse público sobre o particular, Que fez com Que a jưrisprudência pátria reiteradamente a proclamasse como um contrato tipicamente administrativo. (...) 5. Conforme se verifica, o mencionado art. $2^{\circ}$ utilizou o termo "concessáo" referindo-se ao gênero, e não à espécie. Assim o fazendo, tornou necessária a licitação em toda e Qualquer concessão, seja ela "administrativa de uso" ou "de direito real de uso". O Estatuto fez distinção apenas Quanto à modalidade de licitação a ser empregada, tornando obrigatória a realização de concorrência somente para as concessões de direito real de uso. (...)"

Veja-se que o instituto jurídico da locação, embora em muitos pontos similares aos dos institutos públicos antes mencionados, tem sido utilizado apenas nas hipóteses em Que a Administração Pública é a locatária ${ }^{36}$, inclusive por dispensa de licitação ${ }^{37}$.

De todo modo, não há dúvidas de que tanto a locaçâa, como a concessão de uso, por analogia, são serviços, conforme dispôe o inciso ll do artigo $6^{\circ}$ da Lei no 8.666/93, verbis: "II - Serviço - toda atividade destinada a obter determinada utilidade de interesse para a Administração, taís como: (...) locação de bens (...)".

Quanto à Questão de ser, ou não, comum a existência desses serviços nos imóveis da União, a resposta é sim. É freqüente e usual a existência de postos bancários, restaurantes e lanchonetes, bem como outros serviços, no interior de prédios onde funcionam órgãos públicos federais. Assim, essa contratação, de modo algum, pode ser caracterizada como incomum.

${ }^{36}$ Artigo 62, $\S 3^{\circ}$, l, da Lei $n^{\circ} 8.666 / 93$ e artigo 73 , 1l, da Lei $n^{\circ} 8.666 / 93$.

${ }^{37}$ Artigo 24, X, da Lei no 8.666/93: “X - para a (...) locação de imóvel destinado ao atendimento das finalidades precípuas da Administração, cuj̣as necessidades de instalação e localização condịcionem a sua escolha (...)". 
À guisa de levantamento estatístico, veja-se que, de acordo com pesquisa realizada junto ao serviço de apoio ao Núcleo de Assessoramento lurídico da Advocacia-Geral da Uniâo no Rio Grande do Sul, órgão com atribuiçấo constitucional ${ }^{38}$ para examinar as minutas dos editais e contratos administrativos do Poder Executivo da União ${ }^{39}$, somente no ano de 2003 foram analisadas 81 (oitenta e uma) contratações de cessão de uso de bens públicos. E, neste ano de 2004, já foram examinados 158 (cento e cineüenta e oito) procedimentos administrativos com esse objeto.

\section{DOS ÓBICES AO USO dO PREGÃo NO CONTRATO DE RECEITA}

\subsection{O Artigo $5^{\circ}$ do Decreto Nº $3.555 / 00$ e a Lei Nº $10.520 / 02$}

Dispõe o artigo $5^{\circ}$ do Decreto n $3.555 / 00$ : "Alicitação na modalidade de pregão não se aplica (...) às locações imobiliárias e alienações em geral, Que serão regidas pela legislação geral da Administração."

$\mathrm{O}$ leilão ${ }^{40}$ público assemelha-se ao pregão no Que tange à existência de lances ${ }^{41}$. Todavia, como ele se destina à alienação plena da propriedade de bem por parte da Administração Pública, segue o rito do leilão ou da concorrência, com a observância, ainda, das condições previstas nos artigos 24 a 29 da Lei n $9.636 / 98$.

VERA SCARPINELIA $\mathrm{A}^{42}$ entende inadequado o pregão para as locações imobiliárias e alienações em geral, pois:

"(...) se a Administração for a locadora ela desejará celebrar o contrato pelo maior valor possível; e sendo locatária, porQue o bem objeto da locação certamente não será comum, mas específico, determinado, provavelmente único. Quanto às alienações, a incompatibilidade também encontra-se no critério de julgamento, Que será o maior preço ofertado, e rão o menor."

MARÇAL JUSTEN FILHO menciona Que "A regra abrange tanto os contratos em Que a Administração será locatária como os em Que figurará como locadora." ${ }^{43}$ A regra, no

38 Artigo [3] da Constituição Federal.

39 Artigo 38, $\S$ único, da Lei $n^{\circ} 8.666 / 93$.

40 Artigo 22, $\S 5^{\circ}$, da Lei $n^{\circ} 8.666 / 93$ e Artigo 24 da Lei $n^{\circ} 9.636 / 98$.

41 JUSTEN FIL.HO, Marçal. Pregão: (comentários à legislação do pregão comum e eletrônico). SP: Dialética, 2004, p. 18.

${ }^{42}$ SCARPINELLA, Vera. Licitação na Modalidade de Pregăo. SP: Malheiros, 2003, p. 81 :

43 IUSTEN FILHO, Marçal. Pregão: (comentários à legislação do pregão comum e eletrônico). SP: Dialética, 2004, p. 30. 
entanto, não se aplica à situação de locatária da Administração Pública, pois esta, como ele mesmo menciona ${ }^{44}$, vale-se, nesses casos, da dispensa de licitação (artigo 24, X, da Lei $n^{\circ}$ $8.666 / 93)$.

Quanto à posição de locadora da Administração Pública, a situação é diferente, pois o espaço público e com finalidade pública já se encontram definidos. As regras contratuais, igualmente, encontram-se prévia e unilateralmente impostas de acordo com as normas de direito público.

Logo, resta apenas escolher Quem, efetuando a maior oferta de contraprestação mensal e preenchendo os requisitos de habilitação, irá figurar no outro pólo do contrato administrativo. Nesse sentido, bem destaca a Conselheira MARLI VINHADELI, do Tribunal de Contas do Distrito Federal, verbis:

"14. A meu ver, o aspecto principal Que deve nortear a utilização do pregão como modalidade de licitação é que a escolha da Administração deve estar restrita à Questão do preço. Ou seja, dada uma determinada técnica ou especificação do bem, conhecida pelo seu específico mercado, só interessa à Administração contratar com Quem the oferecer o menor preço. (...)

15. Sendo assim, o objeto da licitação na modalidade pregão não pode comportar diferenças significativas de especificação ou de técnica. A vantagem para a administração estará apenas no menor preço, e, não, na escolha deste ou daquele bem, deste ou daquele fornecedor, deste ou daquele prestador de serviço. Qualquer que seja o escolhido, por ofertar menor preço, o beneficio para a Administração deverá ser o mesmo. Daí a natureza de bem ou serviço comum, igual, Qualquer que seja o fornecedor.

16. A vantagem do pregão, em relação às demais modalidades de licitação Que porventura poderiam ser empregadas, está, ao meu ver, na celeridade do procedimento, já que não há necessidade de formulação de propostas singulares, diferenciadas. $\mathrm{E}$, principalmente, na possibilidade de acirramento da concorrência, mediante lances verbaiss, até se chegar ao menor preço ofertado, com claro beneficio financeiro para a Administração. ${ }^{45}$

Assim, feita a devida inversão do crittério de julgamento dos lances, de menor para maior preço, mostra-se evidente que o uso da modalidade do pregão é benéfico à Administração Pública.

44 IUSTEN FILHO, Marçal. Pregão: (comentários à legislação do pregão comum e eletrônico). SP: Dialética, 2004, p. 30.

${ }^{45}$ BRASIL. Tribunal de Contas do Distrito Federal. Decisã̃o $\pi^{\circ} 3639 / 04$ em Processo n० 1630-C, Plenário. Relatora: Conselheira Marli Vinhadeli, Brasília, DF, sessão de 19 de agosto de 2004. 
Mister se faz, ainda, salientar Que: 1 - o rol de serviços comuns do anexo II do Decreto ${ }^{\circ} 3.555 / 00$ não é exaustivo, mas exemplificativo: 2 - as locações (e, por extensão, as concessões de uso) constituem serviços ${ }^{46} ; 3$ - as concessões de uso administrativas não são incomuns nos órgãos públicos; 4 - o Tribunal de Contas da União, em casos de conflito aparente de normas do anexo II com o anexo I do Decreto $n^{\circ} 3.555 / 00$, admite o uso do pregão; 5 - as locações, na Lei no $8.666 / 93$, referem-se à situação de locatária da Administração Pública; 6 - os atos normativos sobre a matéria tratam as locações e as concessões de uso administrativo como se fossem sinônimos; 7 - a Lei no $10.520 / 02$ não recepcionou a restrição imposta pelo Decreto $n^{\circ} 3.555 / 00$ e, portanto, há de prevalecer a vontade legislativa sobre a presidencial; 8 - a Lei $n^{\circ} 8.666 / 93$ versa, precipuamente, acerca de contratos de despesa, e não de receita; 9 - o contrato de concessão de uso é elaborado unilateralmente pela Administração Pública, cabendo apenas escolher o contratado através da maior oferta, o Que pode ser feito através de lances; 10 - a sexta modalidade de lícitação (pregão) também observa os mesmos princípios licitatórios; 11 - também há verificação das condições de habilitação, apenas eue ao final dos lances; e 12 - não se perde a propriedade do bem público, mas apenas a posse direta e temporária de uma parcela do inóvel.

Assim, não se vislumbra Qualeuer risco nessa contratação através do uso da modalidade do pregão como teme MARÇAL JUSTEN FILHO, pois, como ele mesmo afirma: "o pregão realiza os valores de justiça e eliciência tanto Quanto Qualquer outra modalidade licitatória." 47 Como afirma MÁRCIA PELEGRINI: "(...) há relevantes razões de interesse público que justificam a utilização cada vez mais ampla da modalidade." 48

\subsection{O Critério de Julqamento do Prequáo e o Princípio-reqra da leqalidade}

Veja-se que os contratos de receita valem-se das disposições da Lei no $8.666 / 93$, a Qual determinou, nos casos de alienação de bens ou concessão de direito real de uso, a licitação do tipo maior lance ou oferta ${ }^{49}$. Ficou, portanto, sem previsão legal expressa o critério de julgamento das propostas nos casos de concessão administrativa de uso, classificaçăo essa vista, em linhas anteriores, em transcrição de acórdão do Tribunal de Contas da União.

Essa lacuna, contudo, é apenas aparente. É que o artigo $3^{\circ}$ da Lei no $8.666 / 93$ dispõe que a licitação destina-se a "selecionar a proposta mais vantajosa para a Administração" e, de acordo com os tipos previstos no $\S 1^{\circ}$ do artigo 45 da Lei no $8.666 / 93$, a proposta mais vantajosa à Administração, em caso de contrato de receita, será obtida através do maior lance ou oferta.

\footnotetext{
${ }^{46}$ Antigo $6^{\circ}$, 11, da Lei $\pi^{\circ} 8.666 / 93$.

47 JUSTEN FILHO, Marçal. Pregão: (comentários à legislação do pregão comum e eletrônico). SP: Dialética, 2004, p. 42.

18 PELEGRINI, Márcia. Pregão - O conceito de "bens e serviços comuns". BLC -- Boletim de Licitações e Contratos, SP, jun. 2003, p. 399.

49 Artigo 45, § ${ }^{\circ}$, IV, da Lei $n^{\circ} 8.666 / 93$.
} 
Logo, embora a Administração Pública, tecnicamente, só pratieue um ato sob a expressa determinação legal, há casos, como esse, em Que um dispositivo ${ }^{50}$ deva ser utilizado para a complementação de outro ${ }^{51}$, sem Que isso implique em violação ao princípio da legalidade (artigo $3^{\circ}$ da Lei no $8.666 / 93$ ).

Neste momento traz se à colação, ainda, Que, embora os tipos de licitação sejam apenas os taxativamente previstos na Lei de Licitações ${ }^{52}$ (e a Administraçāo Pública somente pode fazer o Que está expressamente previsto na Lei, ao contrário da esfera privada, Que pode fazer o Que não está proibido em lei), o Decreto no $3.892 / 01$, Que trata de aQuisição de passagens aéreas mediante o uso de cartão de crédito corporativo, assim dispóe, verbis.

"Art. 5०. Sem prejuízo das demais cláusulas, o instrumento convocatório de licitação, relativo à prestação de serviços de fornecimento de passagem aérea aos órgãos e às entidades de Que trata o art. $1^{\circ}$, deverá conter. obrigatoriamente, cláusula Que:

(..)

Il - permita o julgamento das propostas com base no maior percentual de desconto oferecido pelas agências de viagens sobre o valor do volume de vendas."

Assim, por força de decreto do Executivo, restou criado um novo tipo de licitação não previsto pelo Legislativo: o do maior percentual de desconto. Claro Que, a fim e ao cabo, o maior percentual de desconto irá trazer o mesmo resultado Que o tipo menor preço, mas não se pode negar que se trata de um outro critério de julgamento de propostas.

ALMIRO DO COUTO E SILVA ${ }^{53}$, no aspecto do princípio da legalidade e da segurança jurídica, assim afirma:

"A dificuldade no desempenho da atividade jurídica consiste muitas vezes em saber o exato ponto em Que certos princípios deixam de ser aplicáveis, cedendo lugar a outros. Não são raras as ocasiōes em Que, por essa ignorância, as soluções propostas para problemas jurídicos têm, como diz Bernard Schwartz, 'toda a beleza da lógica e toda a hediondez da inieüidade'.

A Administração Pública brasileira, na Quase generalidade dos casos, aplica o princípio da legalidade, esquecendo-se completamente do princípio da segurança jurídica. A doutrina e jurisprudência nacionais, com as ressalvas apontadas, têm sido muito tímidas na afirmação do princípio da segurança jurídica.

Ao dar-se ênfase excessiva ao princípio da legalidade da Administração Pública e ao aplicá-lo a situações em Que o interesse público estava a indicar Que não

\footnotetext{
51 Artigo $3^{\circ}$ da Lei no $8.666 / 93$.

51 Artigo 45, $\S 1^{\circ}$, da Lei $n^{\circ} 8.666 / 93$.

52. Artigo $45, \S 1^{\circ}$, I a IV, da Leí $n^{\circ} 8.666 / 93$.

${ }^{53}$ COUTO E SILVA. Almiro do. Princípios da Legalidade da Administração Pública e da Segurança lurídica no Estado de Direito Contemporâneo, RDP, п. 84, p. 62.
} 
era aplicável, desfigura-se o Estado de Direito, pois se lhe tira um dos seus mais fortes pilares de sustentação, Que é o princípio da segurança jurídica, e acaba-se por negar justiça.

Este trabalho não tem outro objetivo senão o de, modestamente, contribuir para Que a injustiça não continue a ser feita em nome da legalidade."

Em apertada síntese, o ensinamento é que, Quando entrarem em colisão o princípio da legalidade e o da segurança jurídica, este prevalece em detrimento daquele, pois o administrado, de boa-fé, possúa a presunção de que o ato havia sido praticado em consonância com a lei.

No entrechoque do inciso $X$ do artigo $4^{\circ}$ da Lei $n^{\circ} 10.520 / 02^{54}$ com o princípioregra da legalidade $e^{55}$, combinados com o princípio-regra da seleção da proposta mais vantajosa para a Administração ${ }^{56}$, todavia, não há espaço para a aplicação do raciocínio do doutrinador sob comento. É Que aquele dispositivo da modalidade do pregão expressamente determina Que o critério de julgamento das propostas será o do menor preço. Não se trata, portanto, de uma colisão de princípios ou de uma aparente lacuna legislativa, como mencionado na situação do parágrafo anterior.

Logo, embora seja extremamente vantajoso para a Administração o uso da modalidade do pregão nos contratos de receita para a concessão administrativa de uso, não há como superar esse óbice trazido pelo princípio-regra da legalidade (critério de julgamento pelo menor preço), pois a proposta mais vantajosa para a Administração é exatamente a inversa (a de maior lance ou oferta).

Poder-se-ia argumentar Que, na colidência do inciso X do artigo $4^{\circ}$ da Lei no $10.520 /$ 02 (menor preço) com o artigo $3^{\circ}$ da Let $n^{\circ} 8.666 / 93$ (proposta mais vantajosa) deveria preponderar este em detrimento daquele. Embora tentadora essa tese, não se pode esquecer Que a Lei $n^{0} 8.666 / 93$ é utilizada apenas de forma subsidiária ${ }^{57}$ àQuela, ou seja. supletivamente $^{58}$, o Que pressupõe a inexistência de norma na Lei $n^{\circ} 10.520 / 02$ (o que não é o caso, pois a lei é clara em estabelecer o critério de julgamento pelo menor preço).

Assim, a concreção da regra (menor preço) em seu sentido diametralmente oposto (maior lance ou oferta) equivale à violação direta daquele texto, pois, por mais elástica que seja a interpretação legal, jamais se chegará ao oposto do texto normativo.

\footnotetext{
\$4 "(...) para julgamento e classilicação das propostas, será adotado o critério de menor preço (...)".

ss Artigo $3^{\circ}$ da Lei $n^{\circ} 8.666 / 93$.

56 Artigo $3^{\circ} \mathrm{da}$ Lei $n^{\circ} 8.666 / 93$.

57 Artigo $9^{\circ}$ da Lei $n^{\circ} 8.666 / 93$.

38 Nesse sentido. "(..) o que se mostra subsidiário, como secundásio, revela, ou pressupöe, o principa/s a que vem, conforme as circunstâncias, auxilar, apoiar, ou reforçar." em SILVA. De Plácido e. Vocabulário jurídico. Rl: Forense, 1993, v. IV. p. 278.
} 
O uso da modalidade de pregão para os contratos de receita, assim, em que se faz necessário o uso do critério de julgamento pela maior oferta ou preço é, portanto, llegal, ante a afronta ao texto do inciso $X$ do artigo $4^{\circ}$ da Lei $n^{\circ} 10.520 / 02$.

A interpretação dessas normas, assim, não pode ultrapassar os limites da reserva legal ou ir diametralmente no sentido oposto ao da vontade legislativa expressa no texto legal, sob pena de restar violado o princípio da legalidade e inválido o ato administrativo praticado.

Conclui-se, portanto, nos termos em que se encontra o texto legal do critério de julgamento da modalidade licitatória do pregão, pela impossibilidade do administrador valerse desse rito para a celebração de contratos de receita.

\section{SITUAÇÃO APRECIADA PELO TRIBUNAL DE CONTAS DA UNIÃo}

O Tribunal de Contas da União, embora não tenha examinado, até o presente momento, nenhum contrato de receita celebrado através da modalidade licitatória do pregão, apreciou situações que se aproximam às concessões administrativas de uso, conforme decisões que se passa a expor:

\section{“(...)}

7. Aliás, a finalidade do pregão (regulamentado pelo Decreto no $3555 / 00$ ) é tornar o procedimento licitatório mais simples sem as amarras da Lei $n^{\circ}$ 8.666/93. Essa nova modalidade, apesar de espelhar-se na referida lei, tem o condão de fluir com mais facilidade devido exatamente a simplicidade de sua concepção.

(...)

15. Dessa forma, a contrataçãao de empresa para prestação de serviços de administração, gerenciamento e manutenção de estacionamento de aeroportos, embora não esteja explicitamente caracterizado como serviço comum no Decreto, a adoção da modalidade pregão, no presente processo, pode, em nosso entendimento, ser considerada viável.

(...)

2. Quanto ao mérito, manifesto-me de acordo com a proposta da Unidade Técnica, no sentido de considerar improcedente a presente representação. pois não restou comprovada irregularidade na escolha da modalidade licitatória (pregão) para contratar os serviços de administraçãa, gerenciamento, operação e manutençâo do estacionamento principal do Aeroporto Internacional de São Paulo/Guarulhos - Governador Franco Montoro. 
3. Há que se ressaltar que o Tribunal já firmou entendimento (...) no sentido de Que a lista de serviços constantes do Anexo II do Decreto n ${ }^{\circ} 3.555 /$ 2000 não é exaustiva, haja vista a impossibilidade de relacionar todos os bens e serviços comuns utilizados pela administração. " ${ }^{59}$

Ao que tudo indica, a situação acima versa sobre um contrato de despesa, cujos recursos captados no estacionamento ingressam diretamente nos cofres da União. Todavia, se essa contratação - mais complexa, inclusive, Que a pura concessão administrativa de uso - fez-se possível mediante o uso da modalidade do pregão, não se vê, salvo a futura mudança legislativa do critério de julgamento para a proposta mais vantajosa à Administraçâo, nos mesmos moldes do artigo $3^{\circ}$ da Lei $\pi^{\circ} 8.666 / 93$, de Qualquer outro óbice às futuras contratações dessa natureza mediante o uso do pregão (presencial ou eletrônico).

\section{DA ALTERAÇÃo LEGISLATIVA}

Para Que se torne viável o uso da modalidade licitatória do pregão nos contratos de receita, mister se faz a alteração do artigo $\left[^{\circ}\right.$, caput, da Lei n ${ }^{\circ} 10.520 / 02$ e do inciso $X$ do artigo $4^{\circ}$ dessa Lei Nacional. Recomendamos, para tanto, respectivamente, as seguintes redaçôes:

"Art. $1^{\circ}$ Para aquisiçãa ou concessão de uso administrativo de bens e de serviços comuns, inclusive sob o regirme de arrendamento, poderá (...)" "Art. $4^{\circ}(\ldots)$

X-para julgamento e classificação das propostas, será adotado o critério do menor preço, nos contratos de despesa, ou o da maior oferta ou lance, nos contratos de receita, observados.(...)"

Assim, procedidas essas alterações legislativas, possível será o uso da novel modalidade licitatória, com evidentes beneficios à Administração e aos administrados.

Não se concorda, todavia, com a posição de MARÇAL JUSTEN FLLHO ${ }^{60}$ de admitir-se um pregão informal em contratação direta sem Que seja seguido o rito da Lei n ${ }^{\circ} 10.520 / 02$, pois, nessa circunstância, se estaria criando um novo rito (metade pregão e metade contratação

${ }^{59}$ BRASIL. Trïbunal de Contas da União. Acórdăo n 434/04 em Representaçăo no 014.048/2002-2, do Plenário. Relator: Ministro Ubiratan Aguiar, Brasilia, DF, sessäo de 14 de abril de 2004, DOU de 29 de abril de 2004.

60 "Não há impedimento à utilização do pregão para outras hipóteses, em Que a Administração estaria legitimada a contratar diretamente. Assim, suponham-se contralaçöes de valor inferior ao limite mínimo determinado no art. 24 , incs. I e li. A Administraçăo poderia promover contrataçöes sem licitaçăo - mas isso não significa contratos näo antecedidos de procedimento prévio, destinado a selecionar a proposta mais vantaj̧osa, com observância (na medida do possível) ao princípio da isonomia. Logo, é perfeitamente possível Que se recorra ao pregăo para obter a solução maiss satisfạtória, mantendo a competitividade sem acréscimo de formalidades desnecessárias" en IUSTEN FLLHO, Marçal. Pregão: (comentários à legislaçäo do pregão comum e eletrônico). SP: Dialética, 2004, p. 35. 
direta), o que é vedado pelo artigo $22, \S 8^{\circ}$, da Lei $n^{\circ} 8.666 / 93$. É que essa "pesquisa de preços" seria feita dentro do contexto de uma modalidade licitatória (pregão) e o resultado dessa pesquisa (o lançador que ofertou o menor preço, em contratos de despesa, ou o de maior lance, nos contratos de receita) seria vinculante à Administração Pública. Logo, não se poderia adjudicar o objẹto pesquisado, mediante contratação direta, a outro fornecedor ou concessionário de uso administrativo. É Que a contratação direta não necessita, sempre, ser feita com o menor preço, desde Que se justifîue a razão da escolha do fornecedor ou executante e o preço esteja dentro do valor de mercado (artigo 26, § único, da Lei $n^{\circ} 8.666 / 93$ ).

A discricionariedade da administração, portanto, reside exatamente no momento da escolha do rito: ou segue o da contratação direta ou segue o do pregão. Caso a Administração escolha pelo da contratação direta, ela justificará o preço de acordo com as suas pesquisas formais e informais de mercado, em nada precisando seguir a Lei $n^{\circ}$ 10.520/02.

\section{CONCLUSÕES}

Após a elaboração deste trabalho, é possivel extrair as seguintes conclusões:

1) A Administração Pública, através do prisma do seu caixa, celebra convênios ou contratos de despesas, de receitas ou sem ônus financeiros.

2) Tem havido pouca preocupação legislativa com os contratos de receita da Administração Pública.

3) A escolha da modalidade licitatória tradicional faz-se através da consideração, por analogia, dos limites pecuniários aos contratos de despesas. Para tanto, multiplica-se o valor de avaliação do bem ou serviço pelo número de meses de vigência do contrato, nele consideradas as eventuais prorrogaçôes e respeitado o limite de sessenta meses.

4) O rol de bens e serviços comuns do anexo II do Decreto no $3.555 / 00$ não é exaustivo. Admitem-se, portanto, outras hipóteses ali não elencadas.

5) Classifica-se o objeto de uma licitação em bem ou serviço de acordo com o seu caráter preponderante (compra, fornecimento, instalação).

6) O pregâo é a sexta modalidade licitatória, distinguindo-se das demais pela sua finalidade: aquisição de bens e serviços comuns, independentemente do valor.

7) Em se tratando de atividades de apoio, a concessão administrativa de uso é feita através da cessão de uso. Nos demais casos, em regra, mediante a cessão de uso sob o regime de arrendamento. A exceção é a da locação administrativa, em Que a Administração Pública figura como locadora de seus bens.

8) A locação é instituto de direito privado e, portanto, a Administração Pública somente se submete a esse regime Quando estiver na condição de locatária. 
9) A locação, por definição legal, é considerada como serviço. A concessão administrativa de uso, por analogia, também é serviço, embora ambos se situem em uma zona gris, na medida em que recaem sobre a tolerância do uso de um determinado bem.

10) Os contratos de concessão administrativa de uso são comuns na Administração Pública. São exemplos os postos bancários, os restaurantes e as lanchonetes existentes nos órgãos públicos.

11) O óbice ao uso do pregão imposto pelo artigo $5^{\circ}$ do Decreto ${ }^{\circ} 3.555 / 00$ não subsiste, pois ele é anterior à Lei $n^{\circ} 10.520 / 02$. A Lei n $n^{\circ} 10.520 / 02$ não proibiu essa atividade, se ela for bem ou serviço comum.

12) O Tribunal de Contas da União, em caso de conflito aparente de normas de mesmo grau hieráreuico, tem decidido pela possibilidade do uso do pregão para bens e serviços comuns.

13) O princípio da legalidade estrita impede o uso do pregão para os contratos de receita, pois o inciso $X$ do artigo $4^{\circ}$ da Lei $n^{\circ} 10.520 / 02$ estipulou o critério de julgamento com base no menor preço. Os contratos de receita, em sentido diametralmente oposto, devem ser julgados com base na maior oferta ou lance.

14) O uso do pregão para os contratos de concessão administrativa de uso é viável e recomendável, desde Que, previamente, seja adequada a Lei n० 10.520/02 para abarcar essas hipóteses.

15) O Decreto $n^{\circ} 3.892 / 01$ restou por criar um novo tipo de licitação não previsto pelo legislador: o do maior percentual de desconto oferecido pelas agências de viagens sobre o valor do volume de vendas. Embora o resultado prálico seja o mesmo, não se pode olvidar que o critério (maior desconto) é diverso do legal (menor preço).

16) O Tribunal de Contas da União tem aceito contratações complexas via modalidade licitatória do pregão em situações próximas à concessão administrativa de uso (exemplo: empresa para administrar, gerenciar e manter estacionamento em aeroportos).

17) Não se admite o uso de pregão informal para as contratações diretas, pois se estaria criando uma nova modalidade licitatória, o que é vedado pelo artigo $22, \S 8^{\circ}$, da Lei $\mathrm{n}^{\circ} 8.666 / 93$. Ademais, o resultado dessa pesquisa informal seria obtido dentro do contexto do rito do pregão, motivo pelo Qual seria inviável contratar pessoa estranha ao vencedor desse certame, o que, em tese, é possível na contratação direta.

18) O momento da discricionariedade da Administração diz respeito ao da eleição do meio (contratação direta ou licitação). 


\section{REFERÊNCIAS BIBLIOGRÁFICAS}

BITTENCOURT, Sidney. Bens e serviços comuns a serem adquiridos ou contratados por meio de pregão. DCAP - Direito Administrativo, Contabilidade e Administração Pública, SP, nov. 2002.

BRASIL. Constituiçăo da República Federativa do Brasil. 29. ed. São Paulo: Saraiva, 2002.

BRASIL. Decreto $n^{\circ}$ 3.555, de 08 de agosto de 2000. Diário Oficial [da] República Federativa do Brasil, Poder Executivo, Brasília, DF, 09 ago. 2000. Seção 1, p. I.

BRASIL. Decreto no 3.892, de 20 de agosto de 2001. Diário Oficial [da] República Federativa do Brasil, Poder Executivo, Brasîlia, DF, 2 I ago. 200I. Seção I, p. I.

BRASIL. Decreto-lei no 9.760, de 05 de setembro de 1946. Diário Oficial [da] República Federativa do Brasil, Poder Exécutivo, Rio de laneiro, R], 06 set. 1946. Seção 1, p. 12500.

BRASIL, Lei $n^{\circ} 9.636$, de 5 de maio de 1998. Diário Oficial \dal República Federativa do Brasil, Poder Executivo, Brasília, DF, 18 maio 1998. Seção 1, p. 2.

BRASIL. Lei no 10.520, de 17 de julho de 2002. Diário Oficial [da] República Federativa do Brasil, Poder Executivo, Brasília, DF, 18 jul. 2002. Seção 1, p. 1.

Saraiva, 2001 .

BRASIl: Licitações e Contratos da Administração Pública. 8. ed. São Paulo:

BRASIL. Supremo Tribunal Federal. Representação de Inconstitucionalidade $0^{\circ}$ 1417/DF, Plenárịo. Relator: Ministro Moreira Alves, Brasília, DF, sessão de 09 de dezembro de 1987, D] de 15 de abril de 1988, p. 8397.

BRASIL. Tribunal de Contas da Uniäo. Acórdão n $615 / 03$ em Representaçâo nº 001.148/ 2003-9, da Primeira Câmara. Entidade: Conselho da Justiça Federal. Relator: Ministro Humberto Guimarães Souto, Brasília. DF, sessão de 01 de abril de 2003, DOU de 09 de abril de 2003.

BRASIL. Tribunal de Contas da União. Acórdão no 434/04 em Representação no 014.048/ 2002-2, do Plenário. Relator: Ministro Ubiratan Aguiar, Brasillia, DF, sessão de 14 de abril de 2004. DOU de 29 de abril de 2004.

BRASIL. Tribunal de Contas da União. Decisão n $207 / 95$ em Processo no TC-275.320/928, da Segunda Câmara. Relator: Ministro Adhemar Paladini Ghisí, Brasília, DF, sessão de 17 de agosto de 1995, DOu de 30 de agosto de 1995.

BRASIL. Tribunal de Contas da União. Decisão nº 674/02 em Representação no TC-015.199/ 0 -3, do Plenário. Relator: Ministro Iram Saraiva, Brasília, DF, DOU de 08 de julho de 2002.

COUTO E SILVA, Almiro do. Princípios da Legalidade da Administração Pública e da Segurança Jurídica no Estado de Direito Contemporâneo, RDP, n. 84, p. 46-63.

JUSTEN FILHO, Marçal. Pregão: (comentários à legislação do pregão comum e eletrônico). SP: Dialética, 2004.

MEIRELLES, Hely Lopes. Direito Administrativo Brasileiro. SP: Malheiros, 2002.

MOTTA, Carlos Pinto Coelho. Pregão: teorịa e prática: nova e antiga idéła em licitação pública. SP: ND|, 2001.

PELEGRINI, Márcia. Pregão - O conceito de "bens e serviços comuns". BLC - Boletim de Licitações e Contratos, SP, jun. 2003.

PEREIRA IĹNIOR, lessé Torres. Pregão, a sextá modalidade de licitação. DCAP ..- Direito Administrativo, Contabilidade e Administração Pública, SP, jun. 2000.

SCARPINELLA, Vera. Licitação na Modalidade de Pregão. SP: Malheiros, 2003.

SILVA, De Plácido e. Vocabulário lurídico. RJ: Forense, 1993. 